\title{
Evaluation of Technology Literation Through Innovation of Autotronic Simulator Assisted Learning in Vocational Schools
}

\author{
Wahid Munawar*, Sriyono, Subhan Nur Sobah, Ridwan Adam \\ Department of Automotive Engineering Education \\ Universitas Pendidikan Indonesia \\ Bandung, Indonesia \\ *wahidmunawar@upi.edu, sriyono@upi.edu
}

\begin{abstract}
The Cruise Control System (CCS) autotronic simulator is an automatic speed control system that functions to maintain the vehicle's speed at the desired speed without stepping on the gas and brake pedals. Autotronic learning innovation in vocational high schools is interpreted as a renewal of the learning process where the teacher originally taught the subject of autotronics using lectures, then innovated by means of the teacher learning using the lectures and the CCS simulator. The aim of this research is to evaluate the results of the innovation of autotronic learning through the use of an autotronic simulator on the aspects of technological literacy. The research method used is pre experimental design (non designs) one shot case study. The research was conducted in February-May 2020. The research location was in a public vocational high school in Bandung. The research sample used simple random sampling of 32 students. Data collection used automotive technology literacy tests. Data analysis using percentages. The results showed that: (1) $58 \%$ of students have literacy in autotronic technology in the aspect of understanding the components and workings of CCS technology; (2) $56 \%$ of students have autotronic technology literacy in the skills aspect of running CCS; and (3) $28 \%$ of students have literacy in autotronic technology in the skill aspect of analyzing disorders of the CCS.
\end{abstract}

Keywords-literac, innovation, simulator

\section{INTRODUCTION}

Ideally, learning in vocational schools aims to produce graduates or people who have the best predicate in knowledge, attitudes and skills in their scientific fields. Therefore, the success of the learning process greatly determines the sustainability and success of the individual in the future. How to provide the best facilities or learning facilities is a challenge for education providers. The best facilities and facilities must ensure that the process becomes easier, cheaper and of higher quality.

The reality in vocational high schools, learning is done conventionally. Many teachers carry out the learning process with the lecture or demonstration method and continue with practical activities in the laboratory/workshop, where students use a practical manual (jobsheet) to practice in the laboratory or workshop.

Limited practice facilities make teachers teach not based on the achievement of student competencies. Likewise, students practice simply carrying out teacher orders through practical work sheets. Learning sources and non-conventional educational media are still not optimally utilized by schools, so that many school graduates do not have competencies that are global character.

The results of observations in a vocational high school in Bandung illustrate the condition of practical facilities with outof-date tools, and limited learning media as well. Limited practice tools and learning media make the learning process not optimal for the teacher.

Ideally, technological learning and technological capabilities are important factors in the occurrence of links and matches between schools and the world of work. Vocational education institutions, especially vocational high schools (SMK) in Indonesia, have not formed graduates who have two balanced skills between hard skills and soft skills [1]. This is related to the educational process in schools, where students get more hard skills but forget soft skills, so that in general the weaknesses of vocational high school graduates in filling job opportunities lies in the problem of personal skills. It is pointed out that there is a difference in goals between the world of education and the industrial world because the world of education wants graduates who have high scores in a fast time, while the industrial world wants graduates with technical competence and good attitudes.

An alternative to problem solving is an innovation in automotive vocational learning using an autotronic simulator to improve technological literacy.

Autotronic learning has learning characteristics that emphasize the ability of hard skills and soft skills. In the knowledge of autotronics, students are expected to be able to 
apply the tools and practical materials of autotronic work when practicing. In autotronic practice, students are expected to have skills in work processes and produce work products that have quality and time standards.

The question in this study is how the autotronic simulator can improve the technological literacy of vocational students.

\section{REVIEW LITERATURE}

\section{A. Literacy of Automotive Technology}

Literacy comes from the Latin word literature which means it is marked by letters, literate, or educated. According to the Maryland Technology Education State Curriculum, technology literacy is the ability to use, understand, organize and assess an innovation that involves process and science to solve problems and expand one's abilities [2]. According to Rose the term technological literacy can be interpreted as: the ability to use technology, especially in learning and teaching science and the ability to inquiry, the ability to evaluate and make decisions [3].

In assessing technological literacy, usually educational researchers or practitioners can use guidance from the ETS (Educational Testing Service). This assessment focuses on the cognitive domain, namely problem solving and critical thinking skills associated with the use of technology to organize information. Measurement of assessment on technological literacy through seven performance areas, namely define, access, manage, integrate, evaluate, create, and communicate [4].

Technological and engineering literacy skills can be measured by tests that refer to the 2014 NAEP framework where there are 3 competencies in technology and engineering literacy assessments, namely: 1. Understand the basic principles of technology, which focuses on students' knowledge and understanding of technology and their ability to think and reason with that knowledge. 2. Develop solutions and achieve goals, which refer to students' systematic application of technological knowledge, tools, and skills to address problems in real social, design, curriculum, and contexts. 3. Communicate and collaborate, centered on the ability of students to use contemporary technology to communicate for various purposes and in various ways, work [5].

\section{B. Simulator of Autotronic Cruise Control System (CCS)}

Simulator is a learning media that can be used to solve problems in the learning process [6]. We believe that simulators can replace many of the expensive practical tools used in workshops. Simulators can be used in many contexts, including simulator technology for job optimization, safety, testing, training and learning. Therefore, simulation tools are continuously being developed and are now important tools in training and learning [7].

Simulator is a teaching model with the assumption that not all learning processes can be carried out directly on the actual object. Rehearsal is an example of a simulator, which demonstrates the process of learning. The simulator process is designed to approach the reality where movements that are considered complex are deliberately controlled [8].

Cruise Control System is a constant speed control system or often called an automatic speed control system (figure 1). This system functions to maintain the vehicle's speed at the desired speed without stepping on the gas and brake pedals. This system is very helpful when on long toll roads. Cruise control system, also known as constant speed drive system, allows the vehicle to automatically change the throttle opening during system activation and continue to run at a stable speed to reduce the driver's driving load [9].

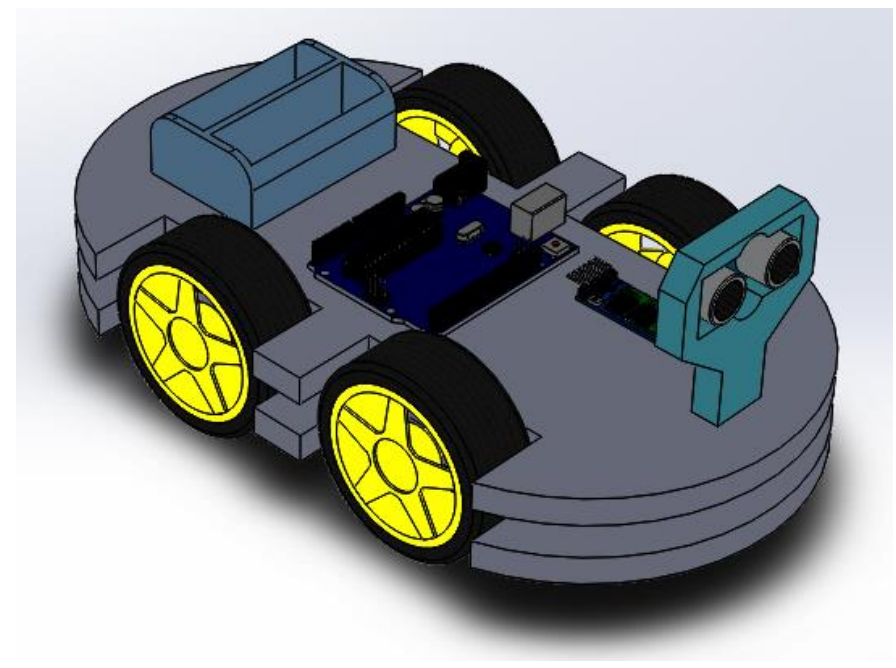

Fig. 1. Simulator CCS (Author)

With the increase in the level of congestion on the road the basic cruise control is less implemented, but now it is being developed again to meet the need to reduce driver fatigue by considering the reality that cruise control is adjusted. The new system is called Adaptive Cruise Control (ACC), which allows your vehicle to follow the vehicle in front of it while adjusting its speed while maintaining a safe distance.

The job of the ACC is to make the vehicle follow its predecessor at a safe distance, and if there is no predecessor blocking it, then drive at a predetermined speed [10]. ACC controls the position and speed of the vehicle. It aims to create a speed error and zero position error. The reference signal in the figure consists of the desired position, speed, and possible acceleration. The desired speed is often the same as the speed of its predecessor. If following another vehicle requires a desired speed which is higher than the preset speed for free driving, this preset speed becomes the desired speed. The desired position usually comes from the desired distance to the predecessor. If there is no previous vehicle to follow, there is no reference position, and only the speed is controlled [11].

Cruise control systems or automatic speed control systems are widely applied to modern vehicles. Without constant speed control the long journey feels more tiring for the driver. With 
the Cruise Control System the driver can maintain the vehicle at the desired speed without stepping on the gas and brake pedals. This system is very helpful when on toll roads.

\section{Innovations of Technology Autotronic Learning}

Innovation comes from English, which means anything that is new or is renewal. Innovation is an idea, item, event, method that is felt or observed as something new for a person or group of people in the form of invention or discovery [12]. Furthermore, innovation is defined as an idea, practice, or object that is considered something new for someone to achieve certain goals [13]. Innovation is also defined as the result of brilliant thinking characterized by new things that can be in the form of certain practices or in the form of human thought and technology used in solving a problem [14]. In some cases, innovation is equated with the term discovery or invention and invention or invention.

The terms innovation do have the same meaning as invention but have fundamental differences. Discovery is the discovery of something that actually already exists but is not known to many people. Invention is interpreted as the discovery of something that is really new and there has been no such thing before, while innovation is an idea, method, and everything that is felt as something new to a group of people.

The theory of innovation in education is a paradigm of an interrelated and inseparable unit between three main pedagogical processes which include creating novelty, mastering it, and applying it [15]. That is, the subject of educational innovation theory is the study of integration of development, mastering it, and its novelty integration. In essence, innovation theory in education is an innovative process in the education system, educational activities, novelty, and the educational environment that exists in the innovation process.

Innovation in education includes all activities in it. Starting from curriculum innovation, learning strategies, learning methods, learning media, and others. In fact, the application of interactive research in education is also categorized as an innovation. Interactive research is an elaboration process between traditional academic research on the one hand and action research on the other [16].

A certain idea or subject can be said to be an innovation if it has several characteristics in it. There are several characteristics in educational innovation, namely: (1) having an identity as a distinctive feature, (2) having novelty or novelty elements, (3) being obtained through a planned process, and (4) having a purpose [17]. So innovation in this research is a learning activity that has novelty or novelty.

The learning innovation assisted by the autotronic simulator in this study means the automotive learning process that has novelty. Automotive learning is carried out by the teacher using a simulator. This is different from the automotive learning done by teachers in the past. The teacher conducts automotive learning by using lectures and referring to textbooks.

Many automotive teachers in the automatic learning process teach using the lecture or demonstration method and continue to practice activities in workshops, where students use practice manuals (jobsheets) to do their practice. In the implementation of practicum activities, the teacher carefully plans a series of direct commands on student activity sheets that lead to the completion of an assignment. Limited practice facilities (laboratories) make teachers teach not based on the achievement of student competencies.

Automotive learning innovation is carried out in the following steps: (1) The teacher makes a cruise control system (CCS) simulator; (2) The teacher tests the simulator; (3) The teacher validates the simulator; (4) The teacher delivers autronic material using the CCS simulator, including: explanation of the use of CCS, explaining the main components of CCS and its functions, how CCS works, comparing CCS tools with other similar tools, analyzing the advantages and disadvantages of CCS; (5) Students practice by running CCS; students analyze the working principles of CCS.

\section{METHODS}

This study aims to determine the technological literacy skills of students in the aspects of knowledge and autotronic competence. This research uses descriptive quantitative method. The study population was all class XI automotive registered in the second semester at one of the State Vocational Schools (SMKN) in Bandung City in the 2019/2020 school year. The research sample was one class of class XI students totaling 32 people with cluster random sampling technique by randomly selecting one class as the research sample [18]. The research instrument was a technology literacy test in the form of a competency test consisting of aspects of CCS technology knowledge and skills. Knowledge aspects at the level of understanding CCS, consist of: (1) explaining the components and functions of the CCS tool, (2) explaining how CCS works, (3) analyzing the advantages and disadvantages of CCS; aspects of skills consisting of; (1) skilled in running CCS and skilled at analyzing work disorders of CCS. The research was carried out in January-March 2020.

\section{RESULTS AND DISCUSSION}

Based on the competency test on 32 students, data on technological literacy was obtained on the competence to understand the components and workings of CCS technology (autotronic), the following research results were obtained: 
TABLE I. TECHNOLOGY LITERACY UNDERSTANDS CCS (AUTOTRONIC)

\begin{tabular}{|c|c|c|c|}
\hline \multirow{2}{*}{ Competency } & \multicolumn{3}{|l|}{ Technological Literacy } \\
\hline & Indicator of Technological Literacy & $f$ & $\%$ \\
\hline \multirow{4}{*}{$\begin{array}{l}\text { Understand the } \\
\text { components and } \\
\text { how CCS } \\
\text { technology works } \\
\text { (auto-tronics) }\end{array}$} & $\begin{array}{l}\text { Able to explain the main } \\
\text { components of CCS autotronic } \\
\text { technology }\end{array}$ & 26 & 81 \\
\hline & $\begin{array}{l}\text { Be able to explain the functions of } \\
\text { CCS components }\end{array}$ & 19 & 59 \\
\hline & $\begin{array}{l}\text { Be able to explain how CCS } \\
\text { works }\end{array}$ & 16 & 50 \\
\hline & $\begin{array}{l}\text { Analyze the advantages and } \\
\text { disadvantages of CCS autotech } \\
\text { technology }\end{array}$ & 13 & 41 \\
\hline \multicolumn{2}{|c|}{$\begin{array}{l}\text { Understand the components and how CCS technology } \\
\text { works (auto-tronics) }\end{array}$} & $\begin{array}{l}74 / \\
128 \\
\end{array}$ & 58 \\
\hline
\end{tabular}

Based on table 1 the results of the study, it could be explained that: (1) $81 \%$ of students had literacy in the ability to explain the main components of CCS autotronic, while $19 \%$ or 6 students did not have the ability to explain the main components of CCS; (2) $59 \%$ of students have literacy in the ability to explain the functions of the CCS autotronic components, while $41 \%$ do not have the ability to explain the functions of the CCS technology components; (3) $50 \%$ of students have literacy in the ability to explain how CCS works, on the contrary $50 \%$ of students do not have the ability to explain how CCS works; (4) $41 \%$ of students have literacy in the ability to analyze the advantages and disadvantages of CCS autotronic technology; (5) $58 \%$ of students have literacy in understanding the components and workings of CCS technology (autotronic).

The results showed that less than half (41\%) of students had low literacy in their ability to analyze CCS. This is presumably because the learning of autronic technology places more emphasis on low critical thinking skills. The contributing factor is not using simulator media in CCS technology learning.

The results of the next technology literacy research are the skills to run CCS and the skills to analyze CCS work disorders.

TABLE II. LITERACY COMPETENCE FOR AUTOTRONIC SKILLS

\begin{tabular}{|l|l|l|l|}
\hline \multirow{2}{*}{ Competency } & \multicolumn{3}{|c|}{ Technological Literacy } \\
\cline { 2 - 4 } & Indicator of Technological Literacy & \multicolumn{1}{|c|}{$\boldsymbol{~}$} & \% \\
\hline \multirow{2}{*}{$\begin{array}{l}\text { CCS autotronic } \\
\text { skills }\end{array}$} & Able to run CCS in automotive & 18 & 56 \\
\cline { 2 - 4 } & $\begin{array}{l}\text { Able to analyze disturbances in } \\
\text { CCS autotronnic }\end{array}$ & 9 & 28 \\
\hline
\end{tabular}

Based on the data from table 2, it is illustrated that: (3) $56 \%$ of students have literacy skills to run CCS; (4) $28 \%$ of students have literacy ability to analyze disorders of autotronic CCS.

The results of the diagnosis of students having low literacy in the competence to analyze disorders of the CCS autotronic are suspected to be the contributing factors: (1) unable to apply knowledge of autotronic; (2) students have never done autotronic learning through simulations.
In order for the learning approach to give optimal results, there are several things that must be considered, including: (a) learning is held with real experiences and an authentic environment that allows a person to process learning to know and learning to do; (b) the content of learning is adapted to the characteristics of students because learning functions as an adaptive mechanism in the process of constructing knowledge, attitudes and abilities.

Therefore, CCS autotronic learning can not only be done using lectures or demonstrations, but requires a simulator and even having to do real work practice in the automotive field.

\section{CONCLUSION}

Technological literacy of school students down to the competence of knowledge of autotronic technology is quite good because more than half $(58 \%)$ of students have literacy to understand the components and workings of CCS technology (autotronic), while technology literacy skills to analyze CCS disorders in students are low because only $28 \%$ of students.

\section{ACKNOWLEDGMENT}

Thanks are conveyed to: Leaders of the University of Education of Indonesia (UPI) through the BOPTN funds for competitive research grants in 2020 .

Thanks are conveyed to the Indonesia University of Education (UPI) for providing research funding assistance for BOPTN competitive research grants in 2020.

\section{REFERENCES}

[1] N. Wibowo, "Upaya memperkecil kesenjangan kompetensi lulusan sekolah menengah kejuruan dengan tuntutan dunia industri," J. Pendidik. Teknol. dan Kejuru., vol. 23, no. 1, pp. 45-59, 2016.

[2] Maryland State Department of Education, "Maryland Technology Education State Curriculum," 2005. Maryland public schools.org.

[3] M.A. Rose, "Perceptions of technological literacy among science technology, engineering, and mathematics leaders," Vol. 19 Issue 1 (fall 2007), 2007.

[4] R. Irvin, "Information and communication technology (ICT) literacy: Integration and assessment in higher education," J. Syst. Cybern. informatics, vol. 5, no. 4, pp. 50-55, 2007.

[5] National Assessment and Educational Progress Abridge Technology and Engineering Literacy framework.National Assesment Governing Board. 2014.

[6] R. Rifdarmon, "Pengembangan Simulator Engine Trainer Integrated Active Wiring Diagram untuk Meningkatkan Efektifitas Pembelajaran Pada Mata Kuliah Listrik dan Elektronika Otomotif," INVOTEK J. Inov. Vokasional dan Teknol., vol. 18, no. 1, pp. 31-38, 2018.

[7] Q.T.T. Bui, P.T. Cat, and K.-S. Hong, "Development of an Electronic Simulator Named 'MPDT' for Control Education," IFAC Proc. Vol., vol. 41, no. 2, pp. 9791-9796, 2008.

[8] S. Rahayu, "Model Simulasi dalam Mata Kuliah Strategi Pembelajaran Fisika," J. Pendidik. Fis. dan Teknol., vol. 1, no. 2, pp. 118-122, 2017.

[9] W.B. Liu, W. Huang, and J. Diao, "Design and Test of Automobile Cruise System Based on PID Control," Intern. Com-bustion Engine Powerpl., vol. 4, pp. 29-31, 2015. 
[10] Y. Ding, H. Ying, and S. Shao, "Typical Takagi-Sugeno PI and PD fuzzy controllers: analytical structures and stability analysis," Inf. Sci. (Ny)., vol. 151, pp. 245-262, 2003.

[11] A. Ganguli and R. Rajamani, "Tractable model development and system identification for longitudinal vehicle dynamics," Proc. Inst. Mech. Eng. Part D J. Automob. Eng., vol. 218, no. 10, pp. 1077-1084, 2004.

[12] U. Syaefudin, "Inovasi pendidikan," Bandung Alf., 2013.

[13] A. Munib, "Karakteristik Inovasi Pendidikan Di Perguan Tinggi Keagamaan Islam," Al-Ulum J. Pemikir. dan Penelit. ke Islam., vol. 3, no. 1 , pp. $75-85,2016$.

[14] D. Nawangsari, "Urgensi Inovasi dalam Sistem Pendidikan,” J. Falasifa, vol. 1 , no. $1,2010$.
[15] N.M. Stukalenko, B.B. Zhakhina, A.K. Kukubaeva, N.K. Smagulova, and G.K. Kazhibaeva, "Studying innovation technologies in modern education.," Int. J. Environ. Sci. Educ., vol. 11, no. 15, pp. 7297-7308, 2016.

[16] J. Burchert, A. Hoeve, and P. Kämäräinen, "Interactive research on innovations in vocational education and training (VET): Lessons from Dutch and German cases," Int. J. Res. Vocat. Educ. Train., vol. 1, no. 2, pp. 143-160, 2014.

[17] S. Silahuddin, "Penerapan E-Learning dalam Inovasi Pendidikan," CIRCUIT J. Ilm. Pendidik. Tek. Elektro, vol. 1, no. 1, 2015.

[18] J.R. Fraenkel, N.E. Wallen, and H.H. Hyun, How to design and evaluate research in education, vol. 7. McGraw-Hill New York, 1993. 